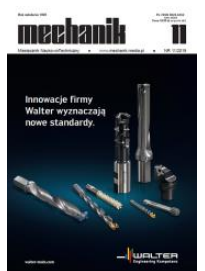

How to cite this article:

Authors: Jan Burek, Artur Szajna

Title of article: „Influence of the lead angle of an spherical diamond head on the roughness parameters of corundum

ceramics"

Mechanik, No. 11 (2019)

DOI: https://doi.org/10.17814/mechanik.2019.11.103

\title{
Influence of the lead angle of an spherical diamond head on the roughness parameters of corundum ceramics
}

\author{
JAN BUREK \\ ARTUR SZAJNA *
}

* Dr hab. inż. Jan Burek, prof. PRz, jburek@prz.edu.pl, https://orcid.org/0000-0003-2664-5248 - Katedra Technik Wytwarzania i Automatyzacji, Wydział Budowy Maszyn i Lotnictwa, Politechnika Rzeszowska, Rzeszów, Polska

Mgr inż. Artur Szajna, a.szajna@prz.edu.pl, https://orcid.org/0000-0002-3820-7272 - Katedra Technik Wytwarzania

i Automatyzacji, Wydział Budowy Maszyn i Lotnictwa, Politechnika Rzeszowska, Rzeszów, Polska

The results of research on grinding of pre-sintered corundum ceramics with the use of a spherical diamond head are presented. In particular, the influence of the angle $\alpha$ of grinding wheel axis on selected surface roughness parameters at variable feed speed have been investigated. The distribution of the effective cutting speed in the contact zone of the grinding wheel with the object for the selected grinding depth have been also determined.

KEYWORDS: grinding, corundum ceramics, spherical diamond grinding wheel, grinding wheel axis angle

\section{Introduction}

The development of technology and as a consequence - increasing demand for more and more resistant and advanced materials has prompted interest in ceramic. Such materials are widely used in medicine as components osteoarticular systems, in dental implantation and also in aviation or automotive industry as engine components. The most popular one is corundum and zirconium ceramics [1,2].

a)

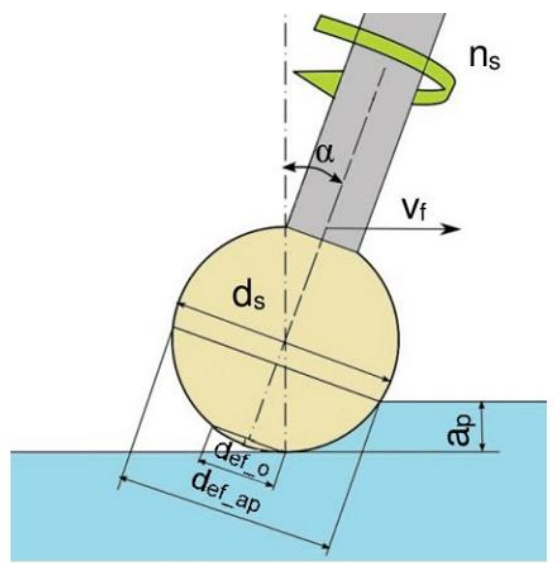

b)

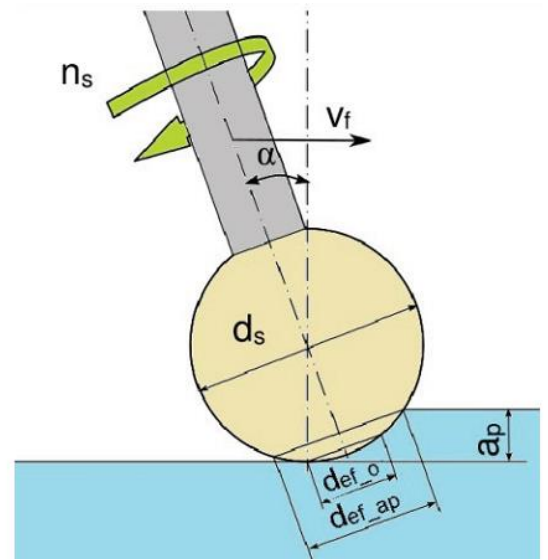

Fig. 1. Impact of the tool angle on the value of the effective diameter of the grinding wheel contact with the object: $a$ ) angle of advance, $b$ ) angle of delay, where: $n_{s}$ - rotational speed of the grinding wheel, $d_{s}$ - grinding wheel diameter, $v_{\mathrm{f}}-$ feed speed, $a_{\mathrm{p}}$ - grinding depth, $\boldsymbol{d}_{\mathrm{ef} \_ \text {ap }}$ - effective diameter of grinding at the machining allowance surface, $d_{\text {ef_o }}$ - effective diameter of cutting at the machined surface

Characteristics of these materials such as hardness, abrasion resistance and at the same time high fragility determine their methods of the treatment. Depending on the stage of ceramic manufacturing process, can be distinguished three states of that material, which limit application of different methods. While in green and partly white state (with the low pre-sintered level) machining is possible (e.g., turning, milling), for higher pre- 
sintered levels and after final sintered there is a need to apply grinding in order to form the final shape and appropriate geometric structure of the shaped part surface [3].

With growing degree of workpiece surface complexity, five-axis grinding machines are used with increasing frequency, on which high spindle speed is achieved, which is required for grinding with spherical diamond heads enabling geometrically complex surface treatment [4].

A significant problem during grinding by spherical diamond heads is their angular orientation in relation to the grinding surface. By analogy with the five-axis milling are distinguished leed angle $\alpha$ and angle of inclination $\beta$ of the grinding wheel spindle that value has impact on cutting speed distribution in the contact zone of grinding wheel with grinded surface (fig. 1).

The aim is to obtain such angular orientation of grinding wheel spindle in relation to the grinding surface to ensure the highest effective grinding speed $[5,6]$.

Influence of angle $\alpha$ (both angle of advance and angle of delay) on distribution effective grinding speed $v_{\text {cef }}$ in the contact zone of grinding wheel with treated surface is presented in Fig. 2 and 3. The analysis was made for constant rotational speed of the grinding wheel $n_{s}=25000 \mathrm{rpm}$, tool nominal diameter $d_{\mathrm{s}}=4,4 \mathrm{~mm}$ and grinding depth $a_{\mathrm{p}}=30 \mu \mathrm{m}$.

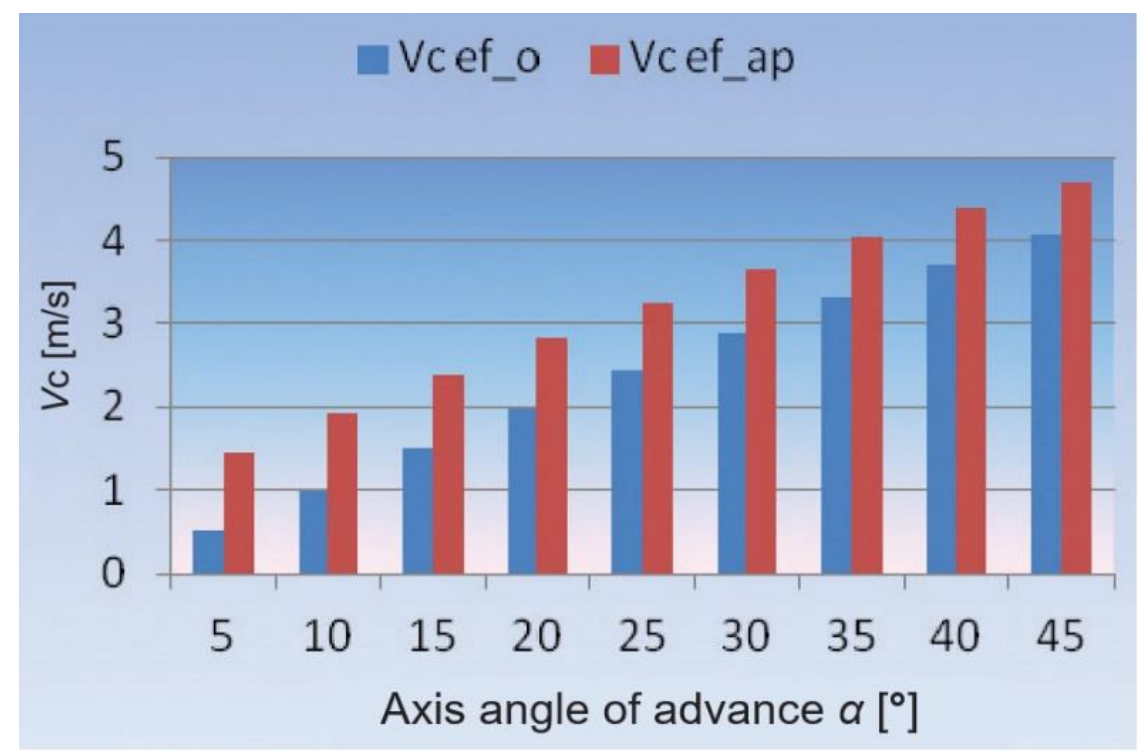

Fig. 2. Distribution of the effective grinding speed $v_{\text {cef }}$ in the contact zone of the grinding wheel and the workpiece for the $\alpha$ angle of delay

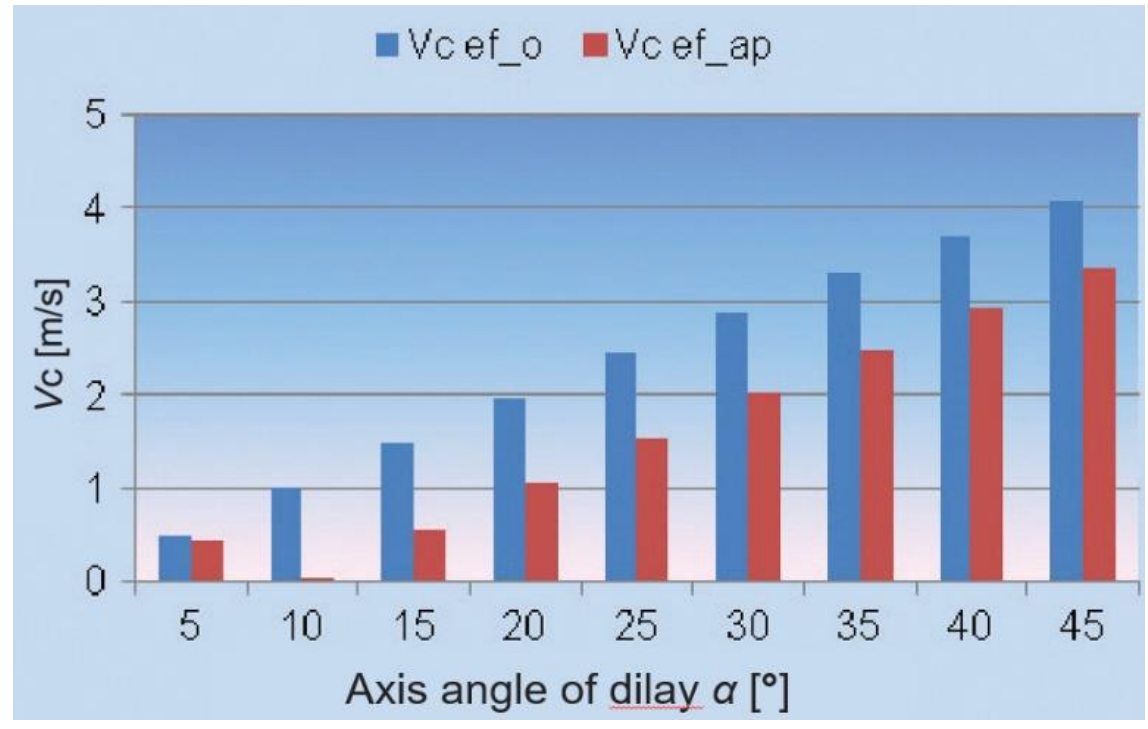

Fig. 3. Distribution of effective grinding speed $v_{\text {cef }}$ in the contact zone of the grinding wheel and the workpiece for the leading angle $\alpha$ 
The presented results demonstrate that angle $\alpha$ settings in both directions (delay and advance) effective grinding speed at already treated surface is identical for both leed angle variants. The difference in distribution of grinding speed develops in the area of contact the tool with upper surface of allowance for the grinding. Much higher values of effective grinding speed in the area of grinding is obtained by using angle of advance. Those values are smaller for angle of delay. This affects geometric structure parameters of the grinding surface.

\section{Test stand and test conditions}

Ceramic grinding tests were carried out on five-axis machining center Ultrasonic 20 linear Sauer company. (fig. 4) based on Sinumerik 840D control system. The aim of this study was to verify the impact of effective grinding speed with positive and negative leed angle $\alpha$ value and feed speed on selected surface roughness parameters.

The samples were made from pre-sintered corundum ceramics. For grinding was used spherical diamond grinding wheel Dremel 7105 with nominal diameter $d_{s}=4,4 \mathrm{~mm}$. The samples are clamped in vise on tilting rotary table.

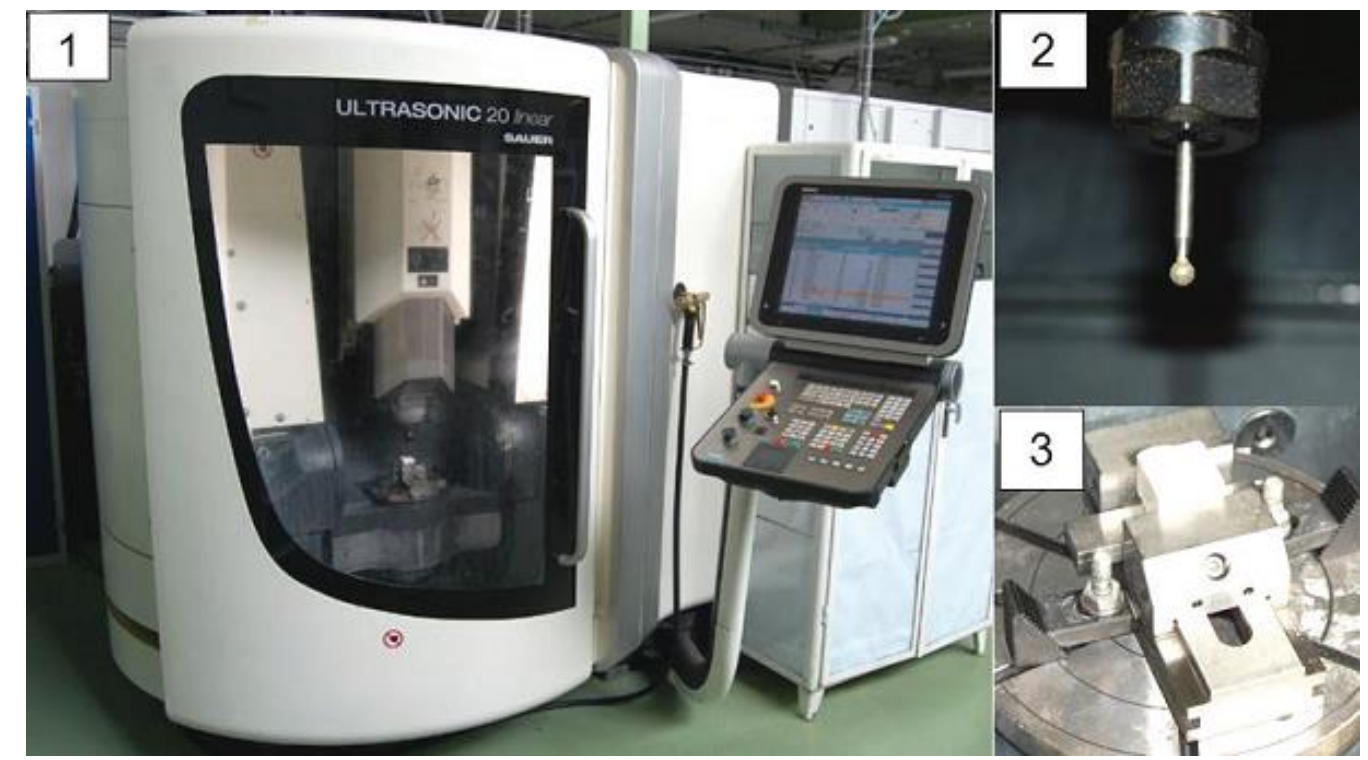

Fig. 4. Test stand: 1 - machine tool, 2 - HSK-A32 holder with Dremel 7105 mounted grinding wheel, 3 - sample

\section{Test conditions}

Six rectangular pre-sustained corundum ceramics samples were prepared. The frontal surface divided into seven parts, in which took place the change of rotational speed of the grinding wheel $n_{s}$ was grinded. The tests were carried out using two grinding wheel mandrel settings - advance and delay. The following parameters have been used:

- variable rotational speed of the grinding wheel $n_{s}(t a b . \mathrm{I})$,

- constant grinding depth $a_{p}=30 \mu \mathrm{m}$,

- constant angle of advance/delay grinding wheel pin axis $\alpha=25^{\circ}$,

- constant angle of inclination $\beta=0^{\circ}$,

- feed speed $v_{f}=200 \mathrm{~mm} / \mathrm{min}, 600 \mathrm{~mm} / \mathrm{min}, 1000 \mathrm{~mm} / \mathrm{min}$,

- constant width of cut $a_{e}$.

For the accepted rotational speeds of the grinding wheel were determined the distribution of effective grinding speed in the area of contact with treated surface (tab. I). 
TABLE I. Distribution of effective grinding speed

\begin{tabular}{|c|c|c|c|c|}
\hline \multirow{2}{*}{$\begin{array}{l}\text { Rotational speed } n_{s} \\
{[\mathrm{rpm}]}\end{array}$} & \multicolumn{2}{|c|}{ Angle of advance } & \multicolumn{2}{|c|}{ Angle of delay } \\
\hline & $v_{c_{-}} O[\mathrm{~m} / \mathrm{s}]$ & $v_{c_{-}} a_{p}[\mathrm{~m} / \mathrm{s}]$ & $v_{c_{-}} o[\mathrm{~m} / \mathrm{s}]$ & $v_{c_{-}} a_{p}[\mathrm{~m} / \mathrm{s}]$ \\
\hline 7000 & 0.14 & 0.4 & 0.14 & 0.13 \\
\hline 10000 & 0.4 & 0.77 & 0.4 & 0.02 \\
\hline 13000 & 0.77 & 1.24 & 0.77 & 0.29 \\
\hline 16000 & 1.26 & 1.81 & 1.26 & 0.67 \\
\hline 19000 & 1.85 & 2.48 & 1.85 & 1.17 \\
\hline 22000 & 2.53 & 3.22 & 2.53 & 1.78 \\
\hline 25000 & 3.3 & 4.03 & 3.3 & 2.48 \\
\hline
\end{tabular}

\section{Tests results}

Measurements of selected roughness parameters of grinding surfaces were performed by portable surface roughness tester MarSurf M 300. The obtained values of selected roughness parameters depending on lead angel $\alpha$ of grinding wheel (angle of advance and angle of delay) and feed speed and rotational speed of the grinding wheel are presented in tables II-IV.

The results prove that choice of angle direction $\alpha$ (angle of advance and angle of delay) has a significant impact on grinding surface roughness, because on this depends effective tool diameter, and from this - grinding speed.

TABLE II. Values of selected roughness parameters obtained at feed rate $v_{\mathrm{f}}=200 \mathrm{~mm} / \mathrm{min}$

\begin{tabular}{|c|c|c|c|c|c|c|}
\hline \multirow{3}{*}{$\begin{array}{c}\text { Rotational speed } \\
n_{s} \\
{[\mathrm{rpm}]}\end{array}$} & \multicolumn{6}{|c|}{$\begin{array}{c}\text { Angle of advance } \\
\text { Feed speed } v_{f}=200 \mathrm{~mm} / \mathrm{min}\end{array}$} \\
\hline & \multicolumn{6}{|c|}{ Type of parameter $[\mu \mathrm{m}]$} \\
\hline & $R a$ & $R q$ & $R z$ & $R p k$ & $R k$ & $R v k$ \\
\hline 7000 & 0.73 & 1.31 & 4.98 & 1.78 & 1.66 & 2.16 \\
\hline 10000 & 0.70 & 0.96 & 4.78 & 0.52 & 1.77 & 2.03 \\
\hline 13000 & 0.43 & 0.63 & 3.13 & 0.29 & 1.13 & 1.35 \\
\hline 16000 & 0.40 & 0.57 & 3.24 & 0.28 & 0.97 & 1.21 \\
\hline 19000 & 0.33 & 0.50 & 2.61 & 0.21 & 0.72 & 1.11 \\
\hline 22000 & 0.31 & 0.52 & 2.49 & 0.26 & 0.67 & 1.14 \\
\hline \multirow{2}{*}{25000} & 0.27 & 0.40 & 2.41 & 0.22 & 0.67 & 0.85 \\
\hline & \multicolumn{6}{|c|}{$\begin{array}{c}\text { Angle of delay } \\
\text { Feed speed } v_{f}=200 \mathrm{~mm} / \mathrm{min}\end{array}$} \\
\hline \multirow{2}{*}{$\begin{array}{c}\text { Rotational speed } \\
n_{s} \\
{[\mathrm{rpm}]}\end{array}$} & \multicolumn{6}{|c|}{ Type of parameter $[\mu \mathrm{m}]$} \\
\hline & $R a$ & $R q$ & $R z$ & $R p k$ & $R k$ & $R v k$ \\
\hline 7000 & 0.67 & 0.96 & 4.66 & 0.45 & 1.56 & 2.30 \\
\hline 10000 & 0.54 & 0.68 & 3.29 & 0.28 & 1.52 & 1.15 \\
\hline 13000 & 0.52 & 0.71 & 3.84 & 0.48 & 1.38 & 1.35 \\
\hline 16000 & 0.48 & 0.90 & 3.55 & 0.27 & 0.88 & 2.20 \\
\hline 19000 & 0.43 & 0.57 & 2.89 & 0.30 & 1.34 & 1.10 \\
\hline 22000 & 0.42 & 0.55 & 2.98 & 0.34 & 1.16 & 1.02 \\
\hline 25000 & 0.39 & 0.54 & 2.71 & 0.27 & 1.09 & 1.14 \\
\hline
\end{tabular}


TABLE III. Values of selected roughness parameters obtained at a feed rate of $\mathrm{vf}=600 \mathrm{~mm} / \mathrm{min}$

\begin{tabular}{|c|c|c|c|c|c|c|}
\hline \multirow{3}{*}{\begin{tabular}{|c|} 
\\
Rotational speed \\
$n_{s}$ \\
{$[\mathrm{rpm}]$}
\end{tabular}} & \multicolumn{6}{|c|}{$\begin{array}{c}\text { Angle of advance } \\
\text { Feed speed } v_{f}=600 \mathrm{~mm} / \mathrm{min}\end{array}$} \\
\hline & \multicolumn{6}{|c|}{ Type of parameter $[\mu \mathrm{m}]$} \\
\hline & $R a$ & $R q$ & $R z$ & $R p k$ & $R k$ & $R v k$ \\
\hline 7000 & 1.39 & 1.85 & 8.05 & 0.90 & 3.93 & 3.91 \\
\hline 10000 & 1.21 & 1.56 & 6.50 & 0.86 & 3.76 & 2.49 \\
\hline 13000 & 0.86 & 1.11 & 4.84 & 0.71 & 2.42 & 1.81 \\
\hline 16000 & 0.57 & 0.73 & 3.45 & 0.40 & 1.68 & 1.13 \\
\hline 19000 & 0.51 & 0.67 & 3.32 & 0.43 & 1.27 & 1.24 \\
\hline 22000 & 0.48 & 0.67 & 3.20 & 0.40 & 1.21 & 1.16 \\
\hline \multirow[t]{2}{*}{25000} & 0.42 & 0.56 & 2.69 & 0.47 & 1.21 & 0.96 \\
\hline & \multicolumn{2}{|c|}{ Feed speed $v_{f}=600 \mathrm{~mm} / \mathrm{min}$} & & & & \\
\hline \multirow{2}{*}{$\begin{array}{c}\text { Rotational speed } \\
n_{s} \\
{[\mathrm{rpm}]}\end{array}$} & \multicolumn{6}{|c|}{ Type of parameter $[\mu \mathrm{m}]$} \\
\hline & $R a$ & $R q$ & $R z$ & $R p k$ & $R k$ & $R v k$ \\
\hline 7000 & 1.56 & 1.92 & 7.33 & 0.95 & 5.27 & 2.39 \\
\hline 10000 & 1.49 & 1.83 & 7.59 & 1.12 & 4.99 & 2.48 \\
\hline 13000 & 1.18 & 1.64 & 6.86 & 1.00 & 3.19 & 3.72 \\
\hline 16000 & 1.00 & 1.27 & 5.57 & 0.78 & 3.23 & 2.15 \\
\hline 19000 & 0.79 & 1.02 & 5.37 & 1.19 & 2.62 & 1.22 \\
\hline 22000 & 0.70 & 0.93 & 4.56 & 0.42 & 1.86 & 1.73 \\
\hline 25000 & 0.68 & 0.87 & 4.10 & 0.48 & 1.95 & 1.37 \\
\hline
\end{tabular}

TABLE IV. Values of selected roughness parameters obtained at a feed rate of $\mathrm{vf}=1000 \mathrm{~mm} / \mathrm{min}$

\begin{tabular}{|c|c|c|c|c|c|c|}
\hline \multirow{3}{*}{$\begin{array}{c} \\
\text { Rotational speed } \\
n_{s} \\
{[\mathrm{rpm}]}\end{array}$} & \multicolumn{6}{|c|}{$\begin{array}{c}\text { Angle of advance } \\
\text { Feed speed } v_{f}=1000 \mathrm{~mm} / \mathrm{min}\end{array}$} \\
\hline & \multicolumn{6}{|c|}{ Type of parameter $[\mu \mathrm{m}]$} \\
\hline & $R a$ & $R q$ & $R z$ & Rpk & $R k$ & $R v k$ \\
\hline 7000 & 2.01 & 2.50 & 10.19 & 2.87 & 5.51 & 3.20 \\
\hline 10000 & 1.71 & 2.12 & 8.83 & 2.10 & 5.59 & 1.80 \\
\hline 13000 & 1.16 & 1.44 & 6.27 & 0.68 & 3.65 & 1.96 \\
\hline 16000 & 0.92 & 1.20 & 5.96 & 0.56 & 2.64 & 2.18 \\
\hline 19000 & 0.82 & 1.09 & 4.76 & 0.71 & 2.45 & 1.92 \\
\hline 22000 & 0.77 & 1.12 & 5.12 & 0.51 & 1.92 & 2.27 \\
\hline 25000 & 0.74 & 0.97 & 4.75 & 0.46 & 2.41 & 1.92 \\
\hline \multicolumn{7}{|c|}{$\begin{array}{c}\text { Angle of delay } \\
\text { Feed speed } v_{f}=1000 \mathrm{~mm} / \mathrm{min}\end{array}$} \\
\hline \multirow{2}{*}{$\begin{array}{c}\text { Rotational speed } \\
n_{s} \\
{[\mathrm{rpm}]}\end{array}$} & \multicolumn{6}{|c|}{ Type of parameter $[\mu \mathrm{m}]$} \\
\hline & $R a$ & $R q$ & $R z$ & Rpk & $R k$ & $R v k$ \\
\hline 7000 & 2.07 & 2.80 & 12.15 & 1.98 & 6.46 & 5.97 \\
\hline 10000 & 1.68 & 2.15 & 9.04 & 2.00 & 4.99 & 3.28 \\
\hline 13000 & 1.34 & 1.71 & 7.42 & 0.91 & 3.83 & 2.75 \\
\hline 16000 & 1.16 & 1.45 & 6.41 & 0.68 & 3.62 & 1.90 \\
\hline 19000 & 0.97 & 1.23 & 5.25 & 0.77 & 2.87 & 1.61 \\
\hline 22000 & 0.91 & 1.14 & 5.12 & 0.61 & 2.91 & 1.64 \\
\hline 25000 & 0.85 & 1.05 & 4.44 & 0.59 & 2.88 & 1.19 \\
\hline
\end{tabular}


The use of angle of advance allowed to obtain lower values of measured roughness parameters than use of angel of delay - both in grinding conditions with different feed speeds and with a changing rotational speed of the grinding wheel. Feed speed had a significant impact on the results. The best results in terms of quality of obtained surface - both angle of advance and angel of delay - achieved for rotational speed $n_{\mathrm{s}}=25000 \mathrm{rpm}$ and feeding speed $\nu_{\mathrm{f}}=200 \mathrm{rpm}$.

\section{Summary}

After analysing surface roughness obtained during grinding tests it was stated that choice of an appropriate grinding wheel pin setting in relation to the grinding surface has a significant impact on the quality of achieved surface. After the application of leading angle has obtained lower values of analysed parameters. Significant impact on the obtained roughness parameters values has also grinding speed. Its increase has caused reduction of roughness parameters values.

\section{REFERENCES}

[1] Burek J.. Szajna A.. Rydzak T. „Wpływ kąta pochylenia osi trzpieniowej diamentowej ściernicy kulistej na chropowatość powierzchni". Mechanik. 8-9 (2018): 706-708. https://doi.org/10.17814/mechanik.2018.8-9.111.

[2] Koprowski J.. Uhlmann E.. Weingaertner W. "Influence of tilt and lead angles on 5-axis grinding with spherical mounted points". Springer. 2018: 11740-11746. https://doi.org/10.1007/s11740-018-0812-5.

[3] Marinescu I.D. "Handbook of Advanced Ceramics Machining". CRC Press Taylor \& Francis Group. 2007: 327-353.

[4] Schmidt Ch. "Koordinatenschleifen dentalkeramischer Werkstoffe mit kleinen Diamantwerkzeugen". Shaker. Aachen 2008.

[5] Mikó B.. Beňo J. „Effect of the working diameter to the surface quality in free-form surface milling”. Key Engineering Materials. 581 (online: October 7 2013): 372-377. https://doi.org/10.4028/www.scientific.net/KEM.581.372.

[6] Burek J.. Żurek P.. Żurawski K. „Wpływ kąta pochylenia na chropowatość powierzchni złożonych po obróbce frezem kulistym". Mechanik 10 (2016): 1478-1479. https://doi.org/10.17814/mechanik.2016.10.419. 